\title{
John A. Fraser
}

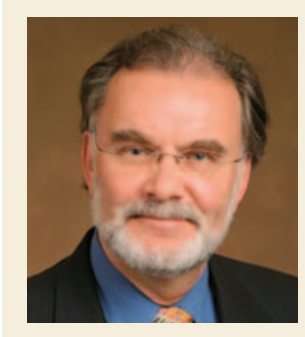

John A. Fraser, President, Association of University Technology Managers and Executive Director, Office of IP Development and Commercialization, Florida State University

John A. Fraser was appointed to his current role of Executive Director of the Office of Intellectual Property Development and Commercialization at Florida State University in 1996 and earlier this year as President of AUTM, the global, academic professional technology transfer association. Before this he served as Director of the University/Industry Liaison Office at Simon Fraser University in Vancouver and he has held several senior positions at technology transfer companies. Fraser has also co-founded three companies and assisted with the launch of 12 technology-based firms.

\section{How do you prioritize different commercial opportunities?}

If the tech transfer office has been given the mandate to make as much money as possible, which is rare, it'll focus on short-term cash flow. But for most of our offices the prime purpose is to enhance the reputation of the institution by helping it create research partnerships with the private sector. Even if your faculty finds a drug that cures cancer in mice, it's going to take a lot of work and money to move it into the marketplace, and so it very much depends on your ability to find a corporate partner. There was an interesting study done at Georgia Institute of Technology and Emory University where they interviewed tech transfer officers, senior research administrators and faculty, and asked them what the priorities for the tech transfer offices were. For administrators the priority was cashflow, for faculty it was the research relationship, and for the tech transfer office it was both. It ultimately depends on the mission of the university.

\section{How did the Bayh-Dole Act affect tech transfer?}

First, it clarified the ownership of inventions that were created using public money inside universities and small companies. Several institutions then formally became much more active in academic tech transfer and our community blossomed. But the entities interested in commercializing academic research also changed. Now, in addition to biopharmaceutical firms we see large and small biotechs and active venture capital firms getting involved. There are also completely new mechanisms for financing biomedical $\mathrm{R} \& \mathrm{D}$ - public-private partnerships and virtual development companies driven by serial entrepreneurs. I think this innovation is traceable back to both the Bayh-Dole Act and the increased flexibility in the way the private sector and academia interact with one another. If there is a downside to this, you could say that when the academic community accelerated corporate financial participation in university research many people felt that taking corporate money was a bad idea. I disagree, but that was the opinion of some.

\section{Are universities now more commercially driven?}

The Bayh-Dole Act had a widespread effect across the entire US. Obviously for the larger urban universities who had been previously active in tech transfer, the Act simply accelerated what they were doing, and building relationships between academia and industry will naturally occur quicker in large cities. AUTM published two Better World reports in March 2006 that highlighted products in the marketplace based on university inventions proving that there was increased commercialization right across the US and Canada. So commercialization activity has increased. But the core missions that drive a university are education, research and clinical care. The AUTM annual survey numbers shows that $\mathrm{R} \& \mathrm{D}$ support from corporations is $\sim 7 \%$ of yearly university research expenditures. Royalty income is $\sim 3-3.5 \%$ of the same expenditures. So although commercialization has increased over the years, it is still a modest part of the research endeavour and just one of many factors influencing the direction of the university.

\section{Is consideration given to whether tech transfer will hinder others' research?}

A major study of the degree to which material transfer agreements hinder research showed that there was no clear evidence of this effect. But it is increasingly becoming an issue; in fact, the NIH has issued a 'best practice' statement about handling research tools. The ownership, via patent, of genes and gene fragments is an emerging issue as well. Twenty-five years ago, when the biotech commercialization of university research began, people realized that the free exchange of materials that existed with their colleagues was changing, so there's been a whole generation of researchers who have grown up with this approach. But the reticence to freely share data is itself changing - there have been discussions about a 'Science Commons' where ideas are moved into the public domain; web sites are appearing to serve as new online platforms for marketing and licensing academic research more quickly. The academic licensing profession itself is showing sensitivity and flexibility to this change using exclusivity specific for each market, permitting multiple commercial partners for a technology.

\section{Canada and the US seem to be tech transfer} torchbearers - what about other countries? The priorities for tech transfer offices and their resources vary between countries. For example, in the UK you find a unique willingness to look at novel and new relationships and, unlike in the US, tech transfer offices in the UK and Canada receive direct government grants. You don't need a Bayh-Dole Act to have a successful programme of tech transfer - you need to be sensitive and aware of the relationship between the private sector and the academic community that already exists, and play to those strengths. Small, dynamic research communities in India and China will be able to look at what's going on in the US, Canada and the UK, and learn from both our successes and mistakes. Increasing globalization will make things easier still. Global corporations, many US headquartered, are beginning to put $\mathrm{R} \& \mathrm{D}$ centres in China and India, where they are ideally located to work with the academic communities in those countries. Non-US-based competitors are seeking US academic research partnerships in a global marketplace. It means that the very best ideas, no matter where they are, will have resources put to them. That can only be a positive thing. 